Paweł FURDYGIEL ${ }^{1}$, Jacek POSTROŻNY², Robert DROBINA ${ }^{3}$

Opiekun naukowy: Robert DROBINA ${ }^{3}$

DOI: https://doi.org/10.53052/9788366249837.06

\title{
OCENA POZIOMU ZAPEWNIENIA BEZPIECZEŃSTWA W OPARCIU O NORME EN ISO 13849 - POZIOM BEZPIECZEŃSTWA (PL)
}

Streszczenie: Celem artykułu jest przedstawienie projektu bezpiecznej maszyny, która powinna spełniać wymagania norm i dyrektyw. Przedstawiono analizę ryzyka metodą graficzną i w programie Sistema, wykorzystując analizę podsystemów bezpieczeństwa maszyny.

Słowa kluczowe: bezpieczeństwo maszyn, dyrektywa maszynowa 2006/42/WE, norma PN-EN ISO 13849-1, MTTFd, PL, PLr, Sistema

\section{ASSESSMENT OF THE LEVEL OF SAFETY PERFORMANCE BASED ON THE STANDARD EN ISO 13849 - SAFETY LEVEL (PL)}

Summary: The purpose of the article presentation of a safe machine design, which should meet requirements of standards and directives. The graphical method of risk analysis is presented and in the "Sistema" program, using the analysis of the machine's safety subsystems. The safety level is also called as a performance level (PL).

Keywords: machine safety, machinery directive 2006/42/EC, standard PN-EN 13849-1, MTTFd, PL, PLr, Sistema

\section{Wprowadzenie}

Dla producenta oraz pracownika podstawę bezpieczeństwa prawnego stanowią bezpieczne maszyny [1]. Użytkownicy sprzętu spodziewają się, że oferowane są tylko pewne i bezpieczne maszyny oraz urządzenia. To przeświadczenie występuje

${ }^{1}$ mgr. inż., Akademia Techniczno-Humanistyczna w Bielsku-Białej, Wydział Budowy Maszyn i Informatyki, specjalność: Inżynieria Produkcji, email: pawe1440@o2.pl

${ }^{2}$ dr inż., Małopolska Uczelnia Państwowa im. rtm. Witolda Pileckiego w Oświęcimiu, Instytut Zarządzania i Inżynierii Produkcji, e-mail: jacek.postrozny@mup.edu.pl

${ }^{3} \mathrm{dr}$ hab. inż., prof. ATH Akademia Techniczno-Humanistyczna w Bielsku-Białej, Wydział Budowy Maszyn i Informatyki, email: rdrobina@ath.bielsko.pl 
na całym świecie. W związku z tym w środowisku obowiązują uregulowania dotyczące ochrony użytkownika maszyn. Posiadają one różną problematykę w zależności od regionu. Istnieje jednak szeroko zaplanowana i przygotowana na dużą skalę zgoda dotycząca procedur stosowanych przy budowie i wyposażeniu maszyn. $\mathrm{W}$ procesie oceny ryzyka bierze udział producent maszyn, który uczestniczy przy ich budowie i ocenia wszystkie możliwe zagrożenia i niebezpieczne miejsca. Adekwatnie do uzyskanej oceny ryzyka wytwórca maszyny musi wyeliminować lub zmniejszyć ryzyko za pomocą odpowiednich środków. Jeśli ryzyka nie da się wykluczyć za pomocą należytych metod konstrukcyjnych lub pozostałe ryzyko nie mieści się w granicach tolerancji, producent maszyny musi wybrać i zastosować odpowiednie osłony i urządzenia ochronne, a w razie potrzeby poinformować o ryzyku resztkowym [1], [2]. Zaprojektowanie maszyny, możliwie najbardziej efektywnej i wydajnej, jest podstawowym celem, którym kieruje się projektant. Budowa takiego urządzenia ma uzasadnienie zarówno ekonomiczne, jak i praktyczne. Dążąc do tego celu, nie można zapominać jednak o szczególnie ważnej kwestii, jaką jest bezpieczeństwo operatora maszyny. Konstruowanie coraz bardziej bezpiecznych maszyn umożliwia postęp techniczny. Jeśli więc maszyna stwarza zagrożenie, to można założyć, że wcześniej czy później nastąpi wydarzenie powodujące szkody związane z tym ryzykiem. Dlatego też istotne znaczenie ma projektowanie i wytwarzanie maszyn, przy obsłudze których zagrożenia są ograniczone tak dalece, jak to jest możliwe przy obecnym stanie wiedzy. Głównym celem pracy jest przedstawienie procedur i możliwości wykorzystania środowiska Sistema w odniesieniu do bezpiecznej maszyny oraz dostosowanie istniejącego urządzenia do podstawowych wymogów, norm i dyrektyw $[3,4]$.

\section{Bezpieczeństwo maszyn i urządzeń - Poziom Bezpieczeństwa (PL)}

W świetle aktualnych zapisów prawnych oraz zaleceń dotyczących eksploatacji maszyn i urządzeń, układ sterowania maszyny, który składa się z poszczególnych komponentów, realizuje nie tylko funkcję bezpieczeństwa, ale również musi spełniać kryteria technologiczne. Elementy powinny być starannie dobrane i wykonane z należytą precyzją, ponadto muszą być dobrane do pracującego środowiska i uwzględnić panujące warunki, w jakich dana maszyna może pracować. Maszyna powinna być bezpieczna i stwarzać bezpieczne warunki przy wszystkich rodzajach pracy. Omawiana norma C [5], która dotyczy bezpieczeństwa określonej maszyny (lub typu maszyny), definiuje wymagany poziom bezpieczeństwa. Poziom bezpieczeństwa maszyny jest określany oddzielnie dla każdej z jej funkcji. Obowiązuje dla wszystkich zastosowanych podzespołów, takich jak: czujniki, urządzenie ochronne, analizujący moduł logiczny, element wykonawczy bądź elementy wykonawcze. Jeżeli dla odpowiedniej maszyny nie istnieje zapis do normy $\mathrm{C}$, lub nie istnieją odpowiednie dane, wymagany poziom bezpieczeństwa określa się w oparciu o normę PN-EN ISO 13849-1.

Bezpieczeństwo pracownika obsługującego konkretną maszynę, np. wyjmującego ręcznie elementy do lub z maszyny wymaga zastosowania nieco innych procedur bezpieczeństwa, aniżeli ochrona operatora pracującego przy maszynie, u którego maksymalne ryzyko ogranicza się do zakleszczenia lub zmiażdżenia kończyn górnych, np. palca. W różnych fazach eksploatacji tej samej maszyny mogą wystąpić 
zróżnicowane zagrożenia, dlatego należy w sposób indywidualny określić funkcje bezpieczeństwa. Podstawą dla wszystkich norm dotyczących bezpieczeństwa maszyn jest określenie następujących parametrów: stopień możliwego uszkodzenia ciała/uszczerbku na zdrowiu, częstotliwość i/lub czas trwania zagrożenia oraz możliwość jego uniknięcia. W praktyce stosuje się graf ryzyka (rysunek 1).

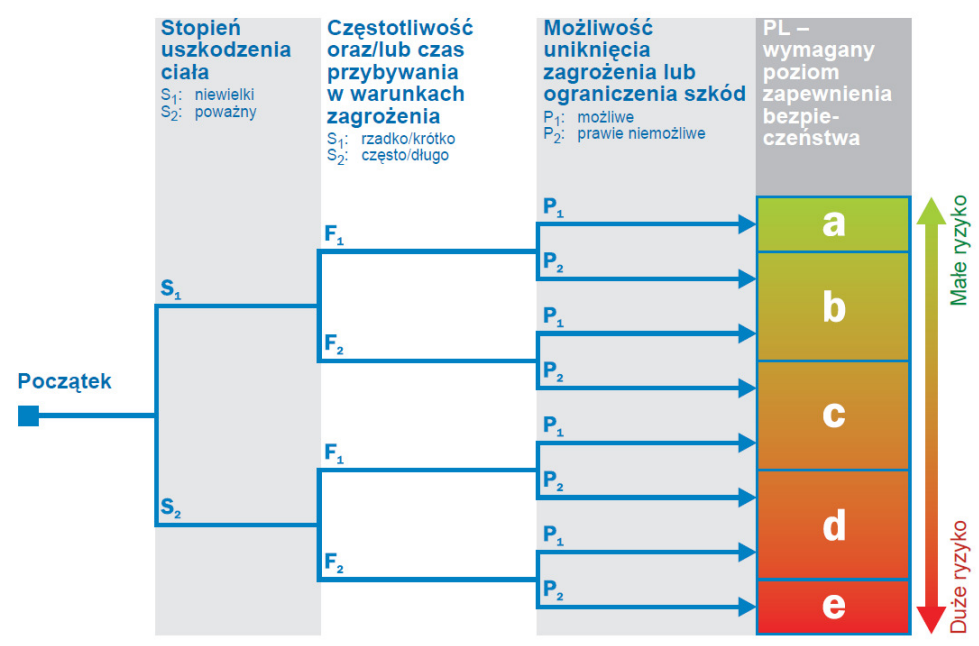

Rysunek 1. Graf ryzyka na podstawie normy EN ISO 13489 [6]

Poziom zapewnienia bezpieczeństwa uwzględnia 5 różnych poziomów. Parametr S1 określa stłuczenia i/lub rany cięte bez dalszych komplikacji, natomiast $\mathrm{S} 2$ - amputację lub śmierć. F1 przyjmuje się, gdy dostęp do strefy niebezpiecznej jest wymagany od czasu do czasu, natomiast F2 - gdy człowiek jest często lub ciągle narażony. P1 oznacza możliwość uniknięcia wypadku lub znaczącego uniknięcia lub ograniczenia jego skutków, zaś P2 - uniknięcie zagrożenia jest niemożliwe.

W świetle danych zawartych na rysunku 2 można określić poziom zapewnienia bezpieczeństwa eksploatowanej maszyny oraz wybrać kategorię poziomu zapewnienia bezpieczeństwa maszyny.

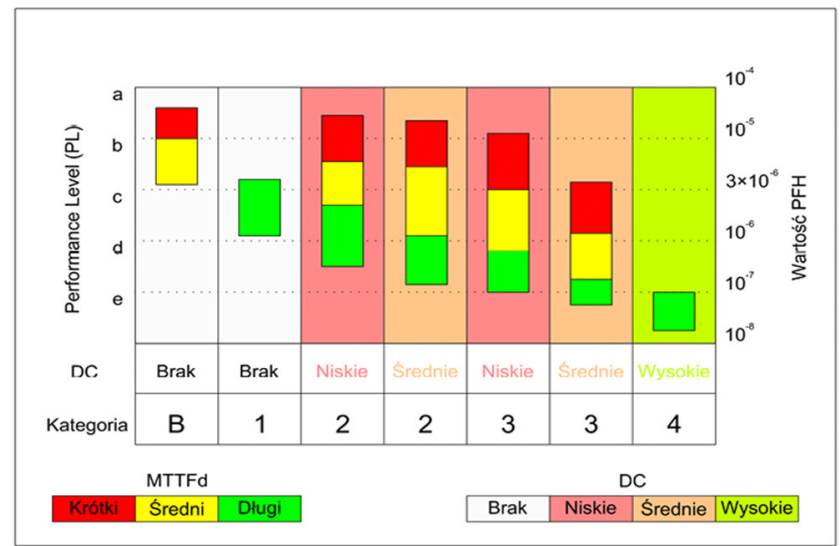

Rysunek 2. Zależności pomiędzy wartościami a poziomem bezpieczeństwa [7] 


\section{Charakterystyka przedsiębiorstwa}

Badania przeprowadzono $\mathrm{w}$ przedsiębiorstwie zajmującym się produkcją i dostarczaniem wyrobów z tworzyw sztucznych oraz metalowych dla przemysłu maszynowego i samochodowego. $\mathrm{Na}$ rysunku 3 przedstawiono strukturę organizacyjną analizowanej organizacji.

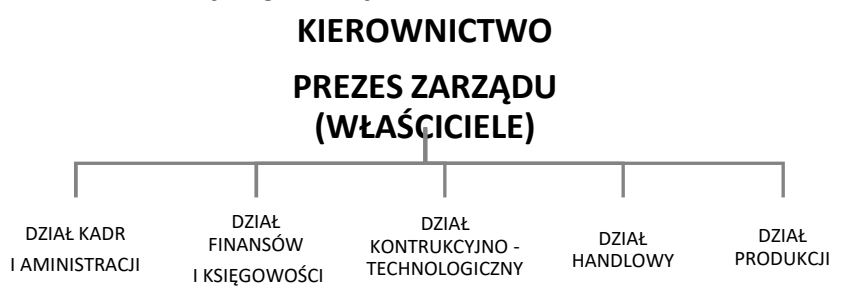

Rysunek 3. Struktura organizacyjna przedsiębiorstwa-opracowanie własne

\section{Projekt bezpiecznej maszyny}

Artykuł przedstawia projekt urządzenia do zagniatania rynienki. Zagniatanie jest to proces (rysunek 4), w którym półwyrób zagniata się do rynienki stalowej o odpowiednich wymiarach $(\phi 6,8 \mathrm{~mm})$. W rezultacie rynienka jest odpowiednio zagniatana do półwyrobu, co uniemożliwia jej spadanie (rysunek 5). Na rysunku 6 przedstawiono szczegółową procedurę uruchomienia i obsługi maszyny, dzięki której ma miejsce realizacja wyżej opisanego procesu.

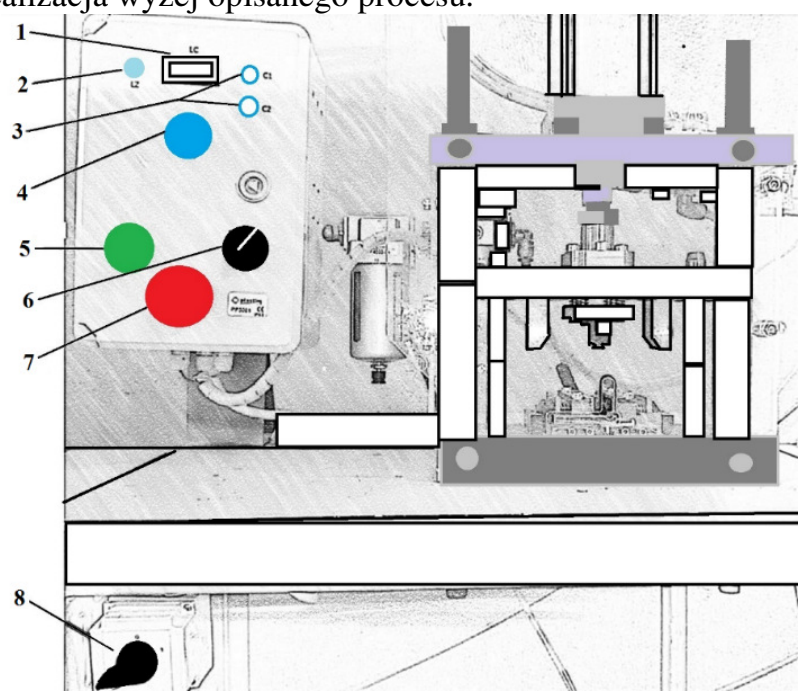

Rysunek 4. Maszyna do zagniatania rynienki, 1 - licznik cykli, 2 - kontrolka

zasilania, 3 - kontrolka czujników, 4-przycisk zerowania licznika, 5-

uruchomienie urzadzenia (w trybie ręcznym), 6 - przełącznik trybu pracy, 7 wyłącznik awaryjny, 8-włącznik zasilania 


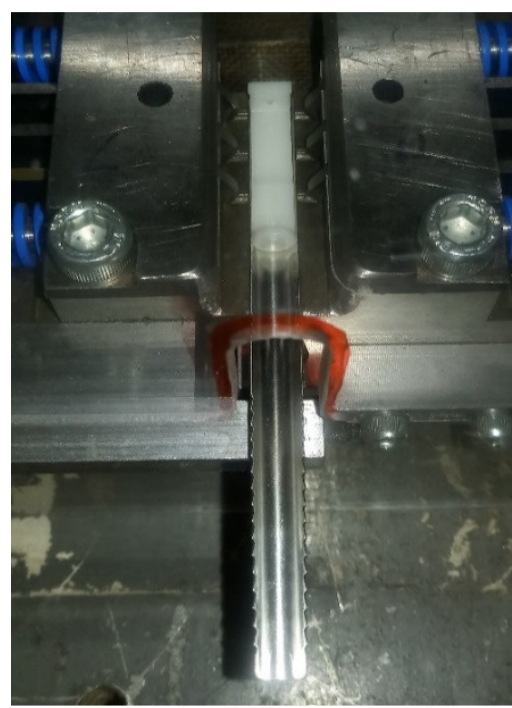

Rysunek 5. Poprawne umieszczenie półwyrobu w urządzeniu

\begin{tabular}{|c|}
\hline $\begin{array}{l}\text { Upewnienie się czy powierzchnia jest sucha i czy za } \\
\text { przezroczystą osłoną nie znajdują się półwyroby lub inne } \\
\text { przedmioty }\end{array}$ \\
\hline$\downarrow$ \\
\hline $\begin{array}{l}\text { Sprawdzenie czy zawór doprowadzający sprężone } \\
\text { powietrze jest ustawiony równolegle do przewodu }\end{array}$ \\
\hline$\downarrow$ \\
\hline $\begin{array}{l}\text { Przekręcić włącznik zasilania na 1, powienien się zapalić } \\
\text { niebieska kontrolka. W przypadku nie zadziałania, sprawdzić } \\
\text { włącznik awaryjny }\end{array}$ \\
\hline$\downarrow$ \\
\hline $\begin{array}{l}\text { Wyzerowanie licznika cykli, niebieskim przyciskiem oraz } \\
\text { ustawienie pokrętłem trybu automatycznego }\end{array}$ \\
\hline$\downarrow$ \\
\hline $\begin{array}{l}\text { Wstępnie zmontowany półwyrób (półwyrób + rynienka) } \\
\text { umiescić w urządzeniu poprzez oznaczony na czerwono } \\
\text { otwór w osłonie }\end{array}$ \\
\hline$\downarrow$ \\
\hline $\begin{array}{l}\text { Sygnalizacja kontrolek czujników C1 i C2 i uruchomienie } \\
\text { stempla zagniatającego }\end{array}$ \\
\hline$\downarrow$ \\
\hline Wyjęcie półwyrobu i umieszczenie nowego \\
\hline$\downarrow$ \\
\hline $\begin{array}{l}\text { Spisanie ilości wykonanych elementów do karty pracy } \\
\text { (uwzględniając produkty wadliwe) }\end{array}$ \\
\hline$\downarrow$ \\
\hline $\begin{array}{l}\text { Przełączenie urządzenia na tryb } 0 \text { oraz przełączenie } \\
\text { włącznika zasilania na pozycję } 0\end{array}$ \\
\hline
\end{tabular}

Rysunek 6. Procedura uruchomienia i obstugi maszyny do produkcji komponentów oraz części wykorzystywanych $w$ urzadzeniach branży tytoniowej 


\section{Ocena ryzyka w odniesieniu do poziomu bezpieczeństwa maszyny}

Na podstawie tabeli 1 oraz tabeli 2 można określić funkcje maszyny oraz operacje, które operator ma do zrealizowania i je wykonuje, w tym: ryzyka niebezpieczeństwa, jakie występują wraz ze środkami bezpieczeństwa. Przykładowo zastosowana osłona, zestaw czujników, które kontrolują i wykrywają metal, umieszczenie danego przedmiotu w gnieździe oraz obecność zaworu odcinającego sprężone powietrze.

Tabela 1. Określenie funkcji maszyny [8]

\begin{tabular}{|c|c|}
\hline $\begin{array}{l}\text { Wykonywane czynności: } \\
\text { (czas/częstość ingerencji) }\end{array}$ & Zastosowane środki bezpieczeństwa \\
\hline $\begin{array}{l}\text { Mocowanie półwyrobu w rynience } \\
\text { stalowej, a następnie umieszczenie } \\
\text { przedmiotu w szczękach, bez } \\
\text { wkładania rąk do strefy niebezpiecznej } \\
\mathrm{E}=10 \\
\text { Prace serwisowe, mechanika, } \\
\text { elektryka, pneumatyka E=2. }\end{array}$ & $\begin{array}{l}\text { Osłony stałe } \\
\text { Osłona nadzorowana w PL e } \\
\text { Odcięcie pneumatyki w PL e } \\
\text { Zatrzymanie realizowane jest w kat } 0 \\
\text { wg PN EN ISO } 13850 \\
\text { Zespół przygotowania powietrza z } \\
\text { ręcznym zaworem odcinającym } \\
\text { (automatyczny spust) }\end{array}$ \\
\hline
\end{tabular}

Ocena podsystemów bezpieczeństwa w maszynie

Tabela 2. Elementy wykonawcze urzadzenia

\begin{tabular}{|c|c|}
\hline \multirow{2}{*}{$\begin{array}{c}\text { Elementy } \\
\text { wykonawcze }\end{array}$} & Maszyna do zagniatania rynienek \\
\cline { 2 - 3 } $\mathbf{N r}$ & obszar: cała maszyna \\
\hline $\mathbf{1}$ & Urządzenie \\
\hline $\mathbf{3}$ & Elektrozawór główny sprężonego powietrza nr 1 \\
\hline $\mathbf{4}$ & Szczęka lewa \\
\hline $\mathbf{5}$ & Szczęka prawa \\
\hline $\mathbf{6}$ & Czujnik szczęki lewej \\
\hline $\mathbf{7}$ & Czujnik szczęki prawej \\
\hline
\end{tabular}

\section{Analiza środowiska oprogramowania Sistema}

Program Sistema umożliwia zaprojektowanie struktury, która pozwoli określić bezpieczeństwo środowiska pracy maszyny. Pozwala osiągnąć i zapewnić poziom bezpieczeństwa PLr (Performance Level). PLr, czyli wymagany poziom bezpieczeństwa, odnosi się do normy PN-EN ISO 13849-1. W programie Sistema można go określić za pomocą metody graficznej (graf bezpieczeństwa). Druga metoda to kategoria bezpieczeństwa, którą wybiera się na podstawie relacji pomiędzy WPR (wskaźnikiem poziomu ryzyka), a KAT oraz PL.

W oprogramowaniu Sistema kategorię bezpieczeństwa wybiera się ręcznie w zakładce „Category”. W przypadku wybrania zbyt niskiej kategorii, program 
automatycznie wskaże błąd. W tym celu należy wprowadzać poszczególne parametry i stosować uzasadnioną systematykę postępowania, która umożliwia zapewnienie zakładanego poziomu bezpieczeństwa PLr dla maszyn.

\section{Szacowanie ryzyka w środowisku Sistema}

Po otwarciu programu Sistema zostanie wyświetlony komunikat (rysunek 7):

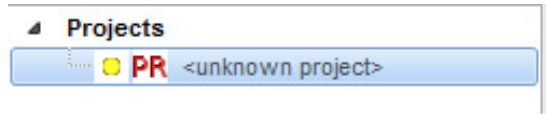

Rysunek 7. Okno projektu

Po utworzeniu nowego projektu, w górnym lewym rogu istnieje możliwość nazwania projektu. PR - Projekt, podsumowanie funkcji bezpieczeństwa. W opisywanym przykładzie uwzględniono maszynę do zagniatania rynienek (rysunek 8).

\begin{tabular}{|c|}
\hline$\quad$ Projects \\
$\vee$ PR Maszyna do zagniatania rynienek
\end{tabular}

Rysunek 8. Nazwany projekt

Następnie, po kliknięciu prawym przyciskiem maszyny na PR, należy kliknąć „,new”. W tym celu ukaże się pole (rysunek 9):

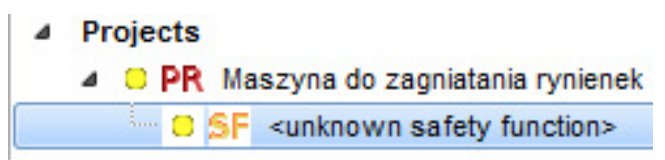

Rysunek 9. Utworzone SF

SF (funkcja bezpieczeństwa) jest to bezpieczna reakcja na zdarzenie nadzorowana magnetycznymi krańcówkami bezpieczeństwa oraz wyłącznikiem awaryjnym. W tym przypadku będzie to: Osłona stała - Zatrzymanie niebezpiecznych ruchów siłownika (rysunek 10).

\ Projects

$\triangle$ PR Maszyna do zagniatania rynienek

SF Osłona stała - Zatrzymanie niebezpiecznych ruchów siłownika

Rysunek 10. Określenie funkcji bezpieczeństwa

Po zaznaczeniu funkcji SF ukaże się okno „Safety function”. W tym polu należy kliknąć zakładkę PLr, która pozwala określić poziom bezpieczeństwa. Jest to metoda graficzna, czyli graf bezpieczeństwa. W tym celu musi być zaznaczone pole: „Determine PLr value from risk graph” (rysunek 11). 


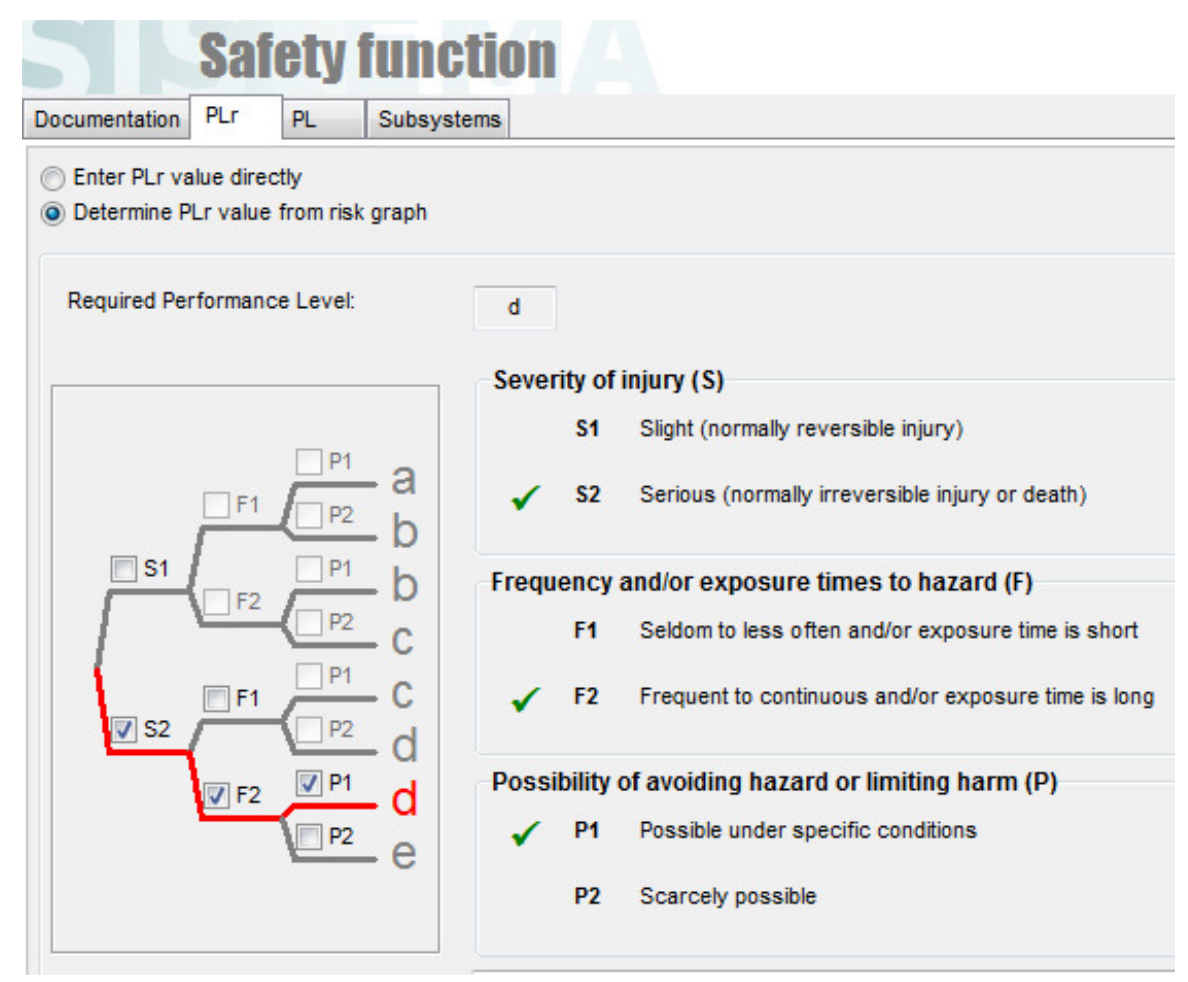

Rysunek 11. Określenie poziomu bezpieczeństwa na podstawie grafu ryzyka: dla urazu S2 - ciężkość urazu poważna, F2 - - częstotliwość wystapienia - często,

$P 1$, który definiuje możliwość uniknięcia lub ograniczenia niebezpieczeństwa,

$d-P L$ - wymagany poziom zapewnienia bezpieczeństwa (duże ryzyko)

W szacowaniu ryzyka zostały uwzględnione trzy parametry. S - ciężkość urazu, $\mathrm{F}$ - narażenie na niebezpieczeństwo, $\mathrm{P}$-prawdopodobieństwo wystąpienia. Wybrano parametr S2 - ciężkość urazu poważna (zazwyczaj nieodwracalne zranienie, śmierć), natomiast parametr, którego nie uwzględniono w projekcie to $\mathrm{S} 1$ - ciężkość urazu lekka (zazwyczaj odwracalne zranienia). F2 oznacza częstotliwość wystąpienia: często. F1 nie uwzględniono, gdyż częstotliwość wystąpienia jest rzadka. Wybrano parametr P1, który definiuje możliwość uniknięcia lub ograniczenia niebezpieczeństwa. Parametr P2 oznacza, iż nie jest możliwe uniknięcie lub ograniczenie bezpieczeństwa, dlatego parametru tego nie uwzględniono. Stosując parametry S2, F2 i P1 osiągnięto poziom PLd, co oznacza zapewnienie bezpieczeństwa wysokiego ryzyka.

Można również określić poziom bezpieczeństwa arbitralnie. Poziom PLe jest ustalany wyłącznie na życzenie klienta (rysunek 12), w szczególności jeżeli chodzi o parametry określane przez klienta w odniesieniu systemu zabezpieczeń. 


\section{Safety function}

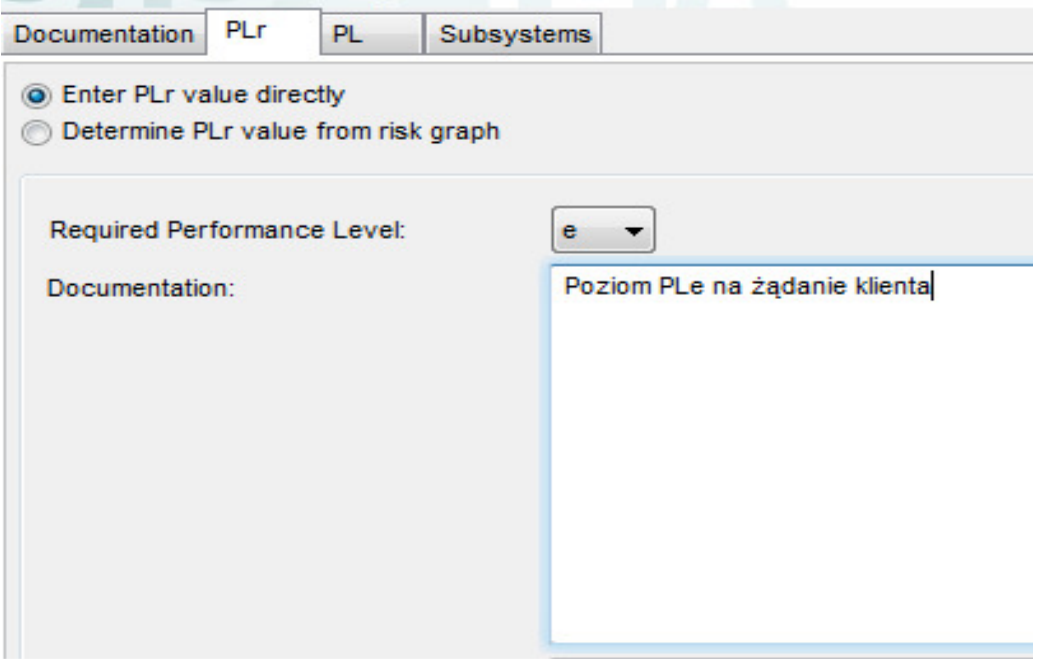

Rysunek 12. Określenie wymaganego poziomu bezpieczeństwa

Do projektu dołączono kolejną funkcję bezpieczeństwa „Zadziałanie wyłącznika awaryjnego - zatrzymanie niebezpiecznych ruchów siłownika” (rysunek 13).

$\triangle$ Projects

$\triangle$ PR Maszyna do zagniatania rynienek

$\checkmark$ SF Osłona stała - Zatrzymanie niebezpiecznych ruchów siłownika

O SF Zadziałanie wyłącznika awaryjnego - zatrzymanie niebezpiecznych ruchów sitownika

Rysunek 13. Utworzona funkcja bezpieczeństwa „Zadziałanie wytacznika awaryjnego - zatrzymanie niebezpiecznych ruchów siłownika"

Dla każdej funkcji bezpieczeństwa utworzono podsystem SB. Może się on składać z grupy bloków strukturalnych albo z elementów bezpieczeństwa ze zdefiniowanymi PL, PFH (PFHD lub PFH $_{\mathrm{D}}$ ) - prawdopodobieństwo niebezpiecznej awarii na godzinę. Jako element wejściowy założono dwukanałowe magnetyczne krańcówki bezpieczeństwa [9], moduł logiczny bezpieczeństwa [10] - przekaźnik bezpieczeństwa [11], element wyjściowy - stycznik odcinający elektrycznie zawory doprowadzające ciśnienie do elementów wykonawczych - siłowniki [12].

W tym celu utworzono 3 podsystemy SB dla SF: „Osłona stała - Zatrzymanie niebezpiecznych ruchów siłownika" (rysunek 14).

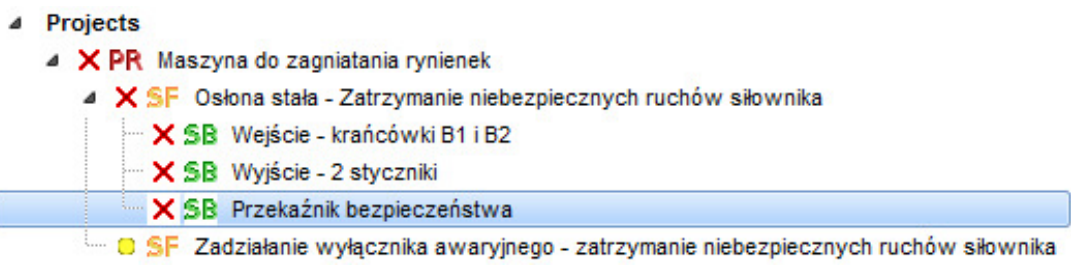

Rysunek 14. Widoczne podsystemy bezpieczeństwa, jako: „,Wejście - krańcówki Bl i B2”, ,Wyjście - 2 styczniki” $i$ „Przekaźnik bezpieczeństwa” 
Następnie dla każdego podsystemu określono parametry bezpieczeństwa:

- struktura (kategoria bezpieczeństwa),

- niezawodność elementów składowych i urządzeń (MTTFd),

- diagnostyka w celu wykrywania defektów (DC),

- odporność na defekty o wspólnej przyczynie (CCF),

- proces (kontrola, walidacja).

Pierwszym parametrem jest PL - Performance Level, czyli poziom zapewnienia bezpieczeństwa. Właściwość ta jest determinowana na podstawie pozostałych parametrów bezpieczeństwa (rysunek 15).

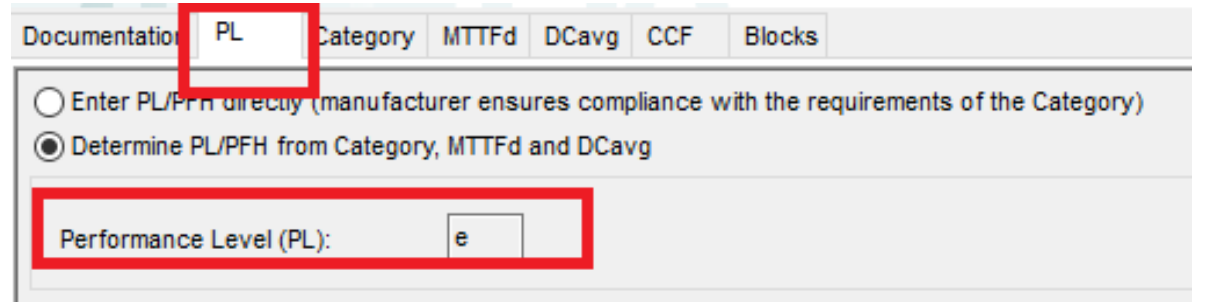

Rysunek 15. Określenie poziomu zapewnienia bezpieczeństwa PL - program Sistema

Kolejnym parametrem bezpieczeństwa jest kategoria bezpieczeństwa. Można ją podzielić na jednokanałowy element zabezpieczający lub dwukanałowy element zabezpieczający. Każdy kanał może zatrzymać niebezpieczny stan. Dwa kanały mogą być też zbudowane w różny sposób (jeden kanał zrealizowany z użyciem elementów elektromechanicznych, drugi na bazie samej elektroniki).

W tabeli 3 przedstawiono podział i właściwości kategorii bezpieczeństwa wraz $\mathrm{z}$ dokładnym opisem wymagań, działania systemu oraz zasady oceny poziomu bezpieczeństwa.

Tabela 3. Podziat i właściwości kategorii bezpieczeństwa

\begin{tabular}{|c|c|c|c|}
\hline Kat. & Opis wymagań & Działanie systemu & $\begin{array}{c}\text { Zasady } \\
\text { uzyskania } \\
\text { bezpieczeństwa }\end{array}$ \\
\hline B & $\begin{array}{l}\text { Związane z bezpieczeństwem elementy } \\
\text { układów sterowania i/lub urządzenia } \\
\text { ochronne oraz ich części muszą być } \\
\text { zaprojektowane, zbudowane, wybrane, } \\
\text { zestawione i połączone zgodnie z } \\
\text { odpowiednimi normami. }\end{array}$ & $\begin{array}{c}\text { Wystąpienie defektu } \\
\text { może spowodować } \\
\text { utratę funkcji } \\
\text { bezpieczeństwa. }\end{array}$ & $\begin{array}{l}\text { Głównie } \\
\text { poprzez wybór } \\
\text { części. }\end{array}$ \\
\hline 1 & $\begin{array}{l}\text { Muszą być spełnione wymagania } \\
\text { kategorii B. Należy stosować } \\
\text { wypróbowane części i wypróbować } \\
\text { zasady bezpieczeństwa. }\end{array}$ & $\begin{array}{c}\text { Wystąpienie defektu } \\
\text { może spowodować } \\
\text { utratę funkcji } \\
\text { bezpieczeństwa, ale } \\
\text { prawdopodobieństw } \\
\text { o pojawienia się } \\
\text { błędu jest mniejsze } \\
\text { niż w przypadku } \\
\text { kategorii B. }\end{array}$ & $\begin{array}{l}\text { Głównie przez } \\
\text { wybór części. }\end{array}$ \\
\hline
\end{tabular}




\begin{tabular}{|c|c|c|c|}
\hline 2 & $\begin{array}{c}\text { Muszą być spełnione wymagania } \\
\text { kategorii B. Musi być zapewnione } \\
\text { stosowanie wypróbowanych zasad } \\
\text { bezpieczeństwa. Funkcja } \\
\text { bezpieczeństwa musi być kontrolowana } \\
\text { w odpowiednich odstępach czasu przez } \\
\text { układ sterowania maszyną } \\
\text { (częstotliwość testów } 100 \text { razy większa } \\
\text { niż częstotliwość wymagana). }\end{array}$ & $\begin{array}{l}\text { Wystąpienie defektu } \\
\text { może spowodować } \\
\text { utratę funkcji } \\
\text { bezpieczeństwa } \\
\text { między kontrolami. } \\
\text { Utrata funkcji } \\
\text { bezpieczeństwa jest } \\
\text { rozpoznawana w } \\
\text { wyniku kontroli. }\end{array}$ & $\begin{array}{l}\text { Głównie } \\
\text { poprzez } \\
\text { strukturę. }\end{array}$ \\
\hline 3 & $\begin{array}{l}\text { Muszą być spełnione wymagania } \\
\text { kategorii B. Musi być zapewnione } \\
\text { stosowanie wypróbowanych zasad } \\
\text { bezpieczeństwa. Związane z } \\
\text { bezpieczeństwem części powinny być } \\
\text { zaprojektowane tak, aby: pojedynczy } \\
\text { defekt w każdej z tych części nie } \\
\text { powodował utraty funkcji } \\
\text { bezpieczeństwa oraz aby pojedynczy } \\
\text { defekt był rozpoznawany zawsze, gdy } \\
\text { jest to możliwe w adekwatny sposób. }\end{array}$ & $\begin{array}{l}\text { W przypadku } \\
\text { wystąpienia } \\
\text { pojedynczego } \\
\text { defektu funkcja } \\
\text { bezpieczeństwa } \\
\text { zawsze pozostaje } \\
\text { zachowana. } \\
\text { Rozpoznawane są } \\
\text { niektóre, ale nie } \\
\text { wszystkie błędy. } \\
\text { Nagromadzenie się } \\
\text { niewykrytych } \\
\text { defektów może } \\
\text { spowodować utratę } \\
\text { funkcji } \\
\text { bezpieczeństwa. }\end{array}$ & $\begin{array}{l}\text { Głównie } \\
\text { poprzez } \\
\text { strukturę. }\end{array}$ \\
\hline 4 & $\begin{array}{l}\text { Muszą być spełnione wymagania } \\
\text { kategorii B. Musi być zapewnione } \\
\text { stosowanie wypróbowanych zasad } \\
\text { bezpieczeństwa. Związane z } \\
\text { bezpieczeństwem części powinny być } \\
\text { zaprojektowane tak, aby: pojedynczy } \\
\text { defekt w każdej z tych części nie } \\
\text { powodował utraty funkcji } \\
\text { bezpieczeństwa oraz pojedynczy defekt } \\
\text { był rozpoznawalny przy albo przed } \\
\text { następnym żądaniem kierowanym do } \\
\text { funkcji bezpieczeństwa lub jeśli to } \\
\text { niemożliwe - aby nagromadzenie się } \\
\text { defektów nie powodowało utarty } \\
\text { funkcji bezpieczeństwa. }\end{array}$ & $\begin{array}{c}\text { W przypadku } \\
\text { wystąpienia błędów } \\
\text { funkcja } \\
\text { bezpieczeństwa } \\
\text { zawsze pozostaje } \\
\text { zachowana. Błędy } \\
\text { są rozpoznawane } \\
\text { odpowiednio } \\
\text { wcześnie, co } \\
\text { zapobiega utracie } \\
\text { funkcji } \\
\text { bezpieczeństwa. }\end{array}$ & $\begin{array}{l}\text { Głównie } \\
\text { poprzez } \\
\text { strukturę. }\end{array}$ \\
\hline
\end{tabular}

Źródło : Na podstawie normy PN-EN ISO 13849-1

Kategorie bezpieczeństwa dobierane są na podstawie relacji pomiędzy WPR (wskaźnikiem poziomu ryzyka) a KAT oraz PL. WPR wylicza się na podstawie wzoru [13]:

$$
W P R=S \cdot W \cdot P
$$

gdzie:

$S$ - wskaźnik urazu określający potencjalne skutki zagrożeń; stanowi wypadkową ciężkości i umiejscowienia urazu $\mathrm{z}$ jednoczesnym oszacowaniem strat materialnych,

$W$ - ekspozycja, czas/częstość narażeń,

$P$ - poziom skuteczności nadzorowania zagrożeń, 
Jeżeli wybrano kategorię niezgodną z PLr, to program natychmiast poinformuje o zaistniałym błędzie.

Wybór kategorii poziomu bezpieczeństwa przedstawiono na rysunku 16.

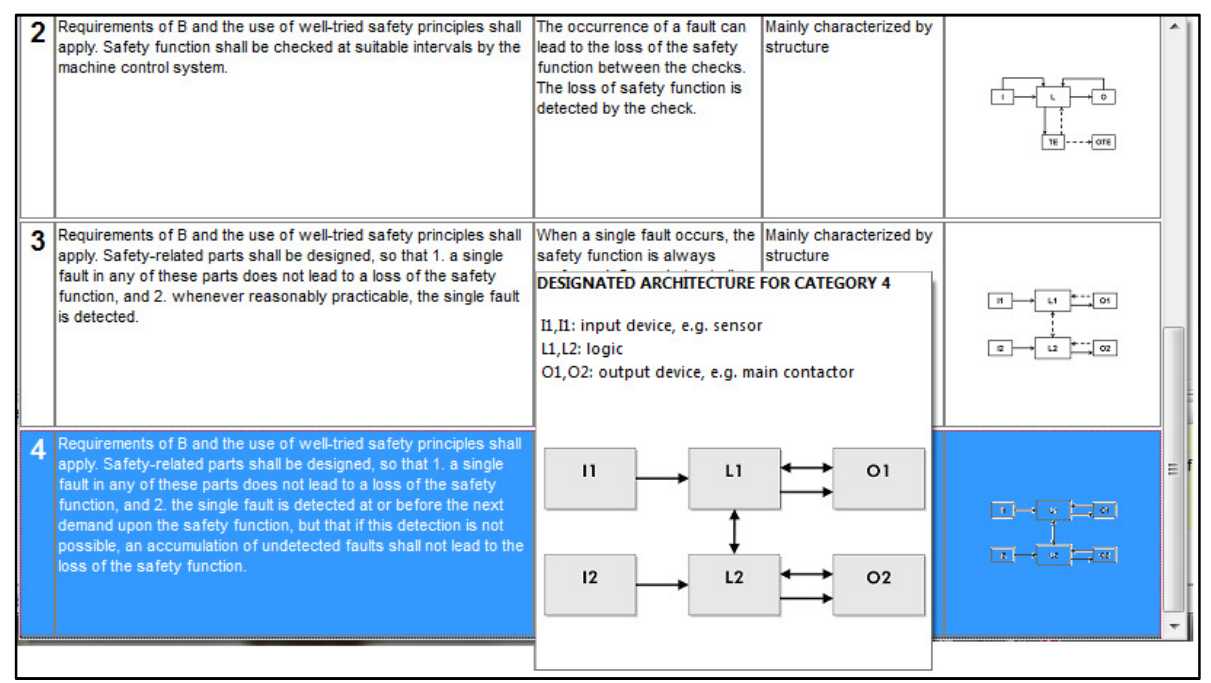

Rysunek 16. Wybór kategorii

Kolejnym krokiem jest określenie MTTFd, czyli średniego czasu do awarii (uszkodzenia), co przedstawia rysunek 17.

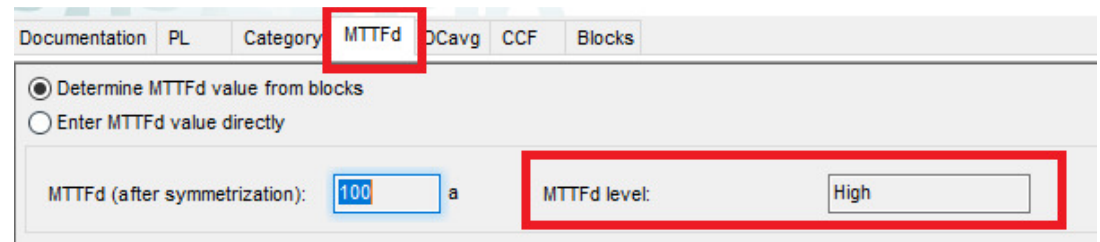

Rysunek 17. Ustawione parametry przez program

Następnie ustawia się DC (pokrycie diagnostyczne), co ilustruje rysunek 18. Parametr ten jest określany w czterostopniowej skali (tabela 4) : 1 - brak, 2 - niskie, 3 - średnie, 4 - wysokie.

Tabela 4. Właściwości parametru DC

\begin{tabular}{|l|l|}
\hline Oznaczenie & Zakres \\
\hline Brak & $\mathrm{DC}<60 \%$ \\
\hline Niski & $60 \% \leq \mathrm{DC}<90 \%$ \\
\hline Średni & $90 \% \leq \mathrm{DC}<99 \%$ \\
\hline Wysoki & $99 \% \leq \mathrm{DC}$ \\
\hline
\end{tabular}




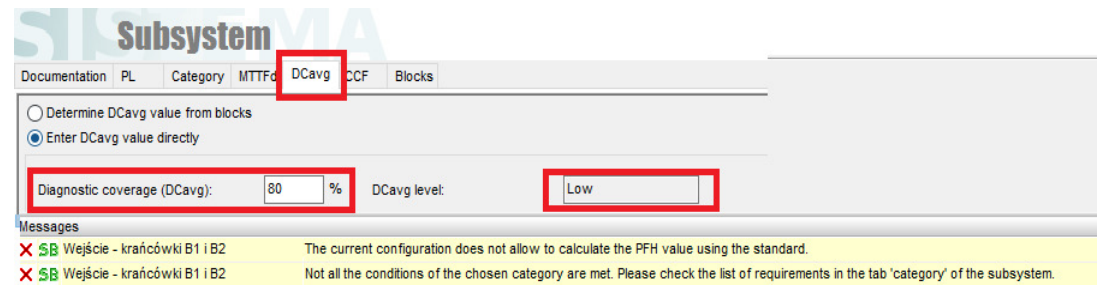

Rysunek 18. Pokrycie diagnostyczne

Ostatnim parametrem, który uwzględniono do określenia, jest CCF - określany jako odporność na uszkodzenia zadane wspólną przyczyną. Przykładowo są to takie usterki, gdzie uszkodzeniu ulegają równocześnie oba kanały z powodu odziaływania czynników zakłócających. Osiągnięcie co najmniej 65 punktów oznacza, że zastosowane środki zapobiegające uszkodzeniom spowodowanych wspólną przyczyną można uznać za wystarczające (rysunek 19).

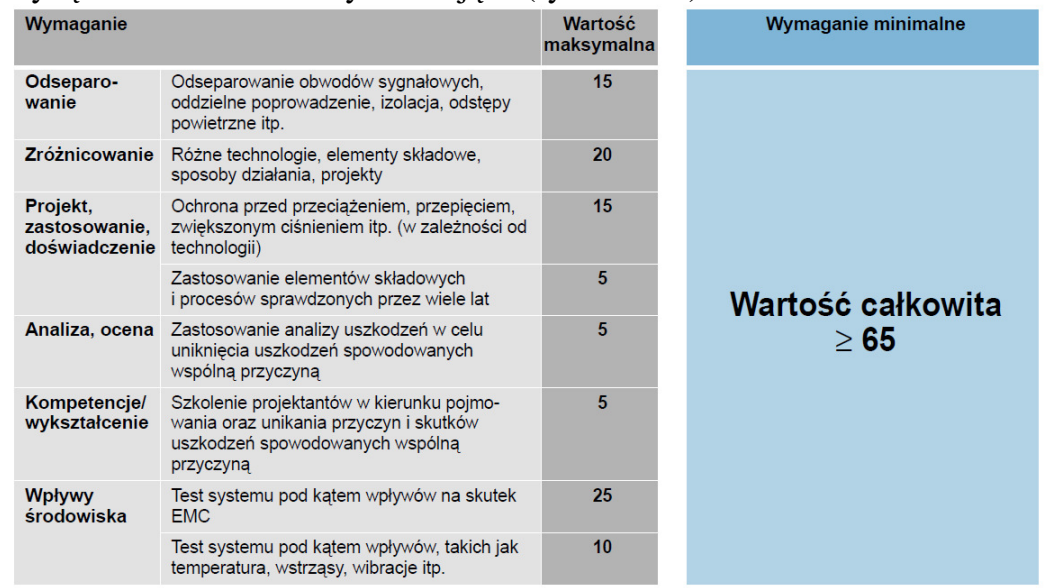

Rysunek 19. Właściwości parametru CCF [14]

\section{Podsumowanie i wnioski}

Środowisko Sistema umożliwia modelowanie i projektowanie urządzeń i maszyn w związku z poprawą bezpieczeństwem ich użytkowania (eksploatacji). Wbudowana baza aktów normatywnych, a także algorytm pozwalają na automatyczne oszacowanie wartości niezawodności oraz wyznaczenie osiągniętego poziomu PL Performance Level (poziom działania, podział od a do e). Praca w systemie pozwala wyznaczyć funkcję bezpieczeństwa zgodnie z normą PN-EN ISO 13849-1, która jest zasadniczą normą dotyczącą bezpieczeństwa dla projektowania systemów związanych z bezpieczeństwem sterowania maszyn, a także w kontekście wymagań zgodnych z Dyrektywą Maszynową 2006/42/WE [1-2]. Na poziom zapewnienia bezpieczeństwa $\mathrm{PLr}=\mathrm{d}$, mają wpływ takie parametry, jak: CCF - środek zapobiegania defektów o wspólnej przyczynie w systemach wielokanałowych (warunek parametru CCF jest spełniony dla CCF $=70 \geq 65$ ), MTTFd - średnia jakość komponentów (wybrana została KAT. 4, czyli MTTFd musi być na poziomie wysokim), DCavg - średnia jakość testu elementów (wynosiła 80\%). Każda 
modyfikacja wymienionych parametrów miała wpływ na ocenę poziomu zapewnienia bezpieczeństwa dla projektowanej maszyny.

\section{LITERATURA}

1. FURDYGIEL P., JANICA P., DROBINA R.: Bezpieczeństwo maszyn w aspekcie aktów prawnych: Wydawnictwo Naukowe Akademii TechnicznoHumanistycznej, Technologie, procesy i systemy produkcyjne, 2020, s. 79-88.

2. Przewodnik Bezpieczne Maszyny, Bezpieczna Maszyna w sześciu krokach: Wydawnictwo SICK Sensor Intelligence 2015 s. 49-131.

3. NEUDÖRFER A.: Konstruieren sicherheitsgerechter Produkte (Konstruowanie bezpiecznych produktów), Springer-Verlag, Berlin et al., ISBN 978-3-642-338892 (5. wydanie 2013).

4. FURDYGIEL P., DROBINA R.: Roboty i coboty wymagania prawne, Wydawnictwo Naukowe Akademii Techniczno-Humanistycznej, Technologie, procesy i systemy produkcyjne, 2020, s. 61-78.

5. Norma PN-EN ISO 12100 Bezpieczeństwo maszyn - Ogólne zasady projektowania - Ocena ryzyka i zmniejszenie ryzyka.

6. FURDYGIEL P., JANICA P., DROBINA R.: Ocena ryzyka w aspekcie maszyn i urządzęń,: Wydawnictwo Naukowe Akademii Techniczno-Humanistycznej, Technologie, procesy i systemy produkcyjne, 2020, s. 89-100.

7. Serwis internetowy: http://automatykaonline.pl/var/aol/storage/images/media/automatyka/au-12_2015/psia-glowicki/ilustracja_02_v2/175744-1-pol-

PL/ilustracja_02_v2_lightbox.png, 13.09.2021.

8. Serwis internetowy: https://www.ciop.pl/CIOPPortalWAR/appmanager/ciop/pl?_nfpb=true\&_pageL abel $=$ P1400137871334834387178\&html_tresc_root_id $=17198 \& h t m l \_t r e s c \_i d=$ 24410\&html_klucz=17198 13.09.2021.

9. Serwis internetowy: https://www.sick.com/pl/pl/wyacznik-bezpieczenstwa/elektromechanicznewyaczniki-bezpieczenstwa/i10r/c/g195505, 13.09.2021.

10. Serwis internetowy: https://automatykaonline.pl/Artykuly/Bezpieczenstwo/Moduly-bezpieczenstwainteligentne-i-programowalne, 13.09.2021.

11. Serwis internetowy: https://www.astor.com.pl/poradnikautomatyka/czym-sa-i-jak-dzialajaprzekazniki-bezpieczenstwa-podstawowe-informacje-ktore-kazdy-automatykznac-powinien/, 13.09.2021.

12. Serwis internetowy: https://www.zawory.org/slownik, 13.09.2021

13. ŁABANOWSKI W.: Bezpieczeństwo użytkowania maszyn poradnik dla pracodawców, Państwowa Inspekcja Pracy, Główny Inspektorat Pracy Warszawa 2012.

14. Serwis internetowy: https://cdn.sick.com/media/docs/8/98/398/special_information_guide_for_safe_ machinery_pl_im0062398.pdf, data odczytu: październik 2021. 